\title{
Middle Class Muslim Women and Beauty Industry
}

\author{
Refti H. Listyani ${ }^{1}$, Emy Susanti ${ }^{2}$, Musta'in Mashud ${ }^{3}$ \\ \{refti.handini.listyani-2018@fisip.unair.ac.id ${ }^{1}$, emy.susanti@ fisip.unair.ac.id², \\ mustain@fisip.unair.ac.id $\left.{ }^{3}\right\}$ \\ Faculty of Social and Political Science, Airlangga University ${ }^{1,2,3}$
}

\begin{abstract}
This research examines disciplining the body of middle-class Muslim women by the beauty industry through halal cosmetics using an ethnomethodology approach. Several theories are employed in this research including the theory of sociology of body, gender perspective and the concept of capitalism. Results indicates that manipulation of the beauty industry places women as active consumers but remains passive at the same time because it cannot fight the flow of legitimacy of this body. The dependence of middle-class Muslim women on beauty products shows that women are now fully under the control of the beauty industry regime which continues to direct the discourse of beauty and women's appearance needs. The beauty of middle-class Muslim women has now been reproduced and discourse uniformly by the beauty industry through halal cosmetics. The implications of this research are this study is expected to contribute information and enrich the repertoire of social science especially sociology also for the development of research on women body, middle class and gender studies.
\end{abstract}

Keywords: body, beauty industry, middle class, women.

\section{Introduction}

Ismail Adam Patel in the book Women, Feminism, and Islam writes that capitalists engaged in the beauty industry have manipulated women to spend more than 33 billion dollars per year on diet products, 20 billion dollars for beauty equipment, 300 million dollars for cosmetic surgery, and more than 7 billion dollars for pornography [1].

Nowadays what is considered beautiful by the industry are those who are tall, slim, straight hair, white, beautiful body. In the days of the Roman empire, beautiful women were those who had a fat and fertile body. No wonder, if at that time, Julius Caesar was infatuated with fertile Cleopatra. While in medieval Europe, women's beauty was measured by their fertility and reproductive abilities. Women will be considered beautiful and sexy if they have large stomachs and pelvis and plump chests, which are body parts related to reproductive function. Whereas in the early 20th century, female beauty was identical to a large buttocks and slim thighs. In Africa and India, women are considered beautiful if they are plump, especially after marriage, because they symbolize the prosperity of their lives. And then the Twiggy era of 1965 emerged, the British model that struck the world with its thin body, then loved by other women [2]. In recent years, beauty trends, especially for Muslim women, are those who wear hijab, following the trend of beauty care, one of which is the use of cosmetics labeled and halal certified. 
Research related to Muslim women, middle class and beauty has been carried out by several researchers, including the following. Safira identified five elements which constitute Islamic advertising in the eyes of Indonesian Muslims. These include compliance with Sharia (Islamic law), the existence of universal Islamic values, relevant execution strategies, advertisement of "Islamic" products and brands, and the use of "Islamic" public figures as celebrity endorsers. Moreover, Indonesian Muslims tend to negotiate between their culture and religion which presents a challenge to the standardization vs. localization of debate in advertising. Islamic advertising was also found to be congruent with the Indonesian Muslims on their emotions, attitudes and behavior. Indonesia is that Islamic advertising able to generate positive word-of-mouth [3].

Soekarba revealed there was not an Islamic theological argument given by women wearing a veil during the interview. By using postfeminist analysis, media and free markets to provide a role model for the modern middleclass Indonesian Muslim women wearing a veil as a good girl and independent woman. On the other hand, those women have conservative values such as marrying at an early age and a rigid gender role. This practice of wearing veil for Muslim women is not Islamization and post-Islamization movement but a pop culture expression to establish them as part of the Middleclass group [4].

The research of Beta explains that the Hijabers are critical of conventional perceptions of religious values and norms, and yet they decide that a part of them wants to celebrate their religiousness as well as their ability to play with the tools they have at their disposal to express their modesty and youthfulness. Their ability to act as consumers while extracting the meanings of traditionally perceived areas as Islamic as well as non-Islamic aspects has brought different sets of contemporary to contemporary Muslim societies in Southeast Asia, particularly Indonesia [5].

Wong have shown that globalization has impacted unevenly on the Malaysian social formation and unleashed different responses amongst the various groups and classes in Malaysia. It has enabled a new (Malay) middle class to be constituted but at the same time, this new middle class becomes an ideological battleground where the tensions between different interpretations of Islam on the one hand and consumption on the other are played out. The sacralication of material objects and practices can occupy a central place in Muslim self-identity as a marker of both material and spiritual success, a process rather not dissimilar to Weber's Protestant ethic [6].

According to Ali etc.al., beauty is one of the biggest realities in this world everyone likes to look beautiful and beauty around, that's why in modern age expense on cosmetics increase. Cosmetics are articles that used to increase beauty. There are many types and categories of cosmetics. Muslims are bound to religious requirements in every sphere of life, including cosmetics, therefore, there is a big scope for halal cosmetics industry to flourish and earn the profit. It is a source of marketing expansion. Non-Muslims also attract towards halal cosmetics for its natural, environmentally friendly and green ingredients [7].

\section{Method}

This research uses ethnomethodology approach. The main data collection technique in ethnomethodology research is the observation of the use of halal cosmetic products by middleclass Muslim women as a form of social piety. Ethnomethodology was originally a creation of Harold Garfinkel (1967). Ethnomethodology which is based on ideas that show daily activities 
and routine social interactions, and general, may be done through various forms of expertise, practical work, and certain assumptions. Expertise, practical work, and assumptions called ethnomethodology. The main purpose of ethnomethodology is to study how community members during social interactions take place, create a sense of indexical expression. The term indexical does not mean universal but depends on the context (for example, he, they). Its nature is limited to being indexed or referenced. Ethnomethodology emphasizes and recognizes the fact that lay people try to recognize social explanations as scientists do [8].

Ethnomethodology approach is a research method observe individual behavior in taking actions that they realize, ways action or the way they learn to action. Ethnomethodology is a group of methods in the domain of qualitative research which focuses its study on reality that has practical interpretation. Included in qualitative research is ethnomethodology research produce descriptive data, ie data originating from observation of a speech, writing, and behavior of the subjects being observed. Within the framework of qualitative research, ethnomethodology is positioned as a theoretical foundation in the method. Ethnomethodology as a study in the subjective world, about awareness, perception and individual actions in their interactions with the social world they occupy in accordance with the subject of qualitative research which also emphasizes the world subjective with the social settings involved. This approach refers to study of how individuals create and understand everyday life they. Ethnomethodology tries to explain how people act to see, explain, and explain order in the world where they live [8].

\section{Result and Discussion}

\section{Middle class Muslim women in Surabaya}

Based on Giddens' analysis, urban middle class Muslims are modern humans, namely humans who able to carry out reflection projects by constructing themselves to find selfidentity among number of strategies and choices provided by abstract systems. One way they do is to open themselves to others or changes that have occurred. This change appears to be seen in how they interpret clothing models and their accompanying attributes, which of course in their view are in accordance with religious provisions. They meet and compound between modernity and religious guidance. The symbols and icons that appear give birth to hybridity which will then continue to emerge new traits and negate certain traits previously possessed. As explained by Weber, a rational person will choose which tool is the most correct to achieve his goal. The pattern of urban Muslim middle class action lies at the level of instrumental rationality, that they not only determine the goals to be achieved, but he has rationally been able to determine the tools (instruments) that will be used to achieve these goals. The look of fashion, body care, and the use of various beauty products are instruments used by urban Muslim women of this middle class to achieve the goal of becoming modernist Muslims, shown in table 1 [9], [10]. 
Table 1. Qibla Comparison of Popular Islamic Culture and Indonesian Middle Classes Muslim [10].

\begin{tabular}{lll}
\hline Qibla Culture & \multicolumn{1}{c}{ Product Form } & \multicolumn{1}{c}{$\begin{array}{c}\text { Muslim Case Examples } \\
\text { Middle class }\end{array}$} \\
\hline \multirow{2}{*}{ Mesir-Turki } & $\begin{array}{l}\text { Nasyid, Hijâb Turban, Ikhwanisme, } \\
\text { recitation of Sufism, and other } \\
\text { modern Islamic products }\end{array}$ & $\begin{array}{l}\text { Campus intellectual groups, } \\
\text { urban middle class groups, and } \\
\text { ta'lîm assemblies }\end{array}$ \\
Arab Saudi & $\begin{array}{l}\text { Short pants for beard and mustache } \\
\text { maintenance, veil usage, and so on }\end{array}$ & $\begin{array}{l}\text { Hard-liner Middle Class groups } \\
\text { such as HTI and MMI }\end{array}$ \\
& $\begin{array}{l}\text { Reading of Barzanji, Shalawat, } \\
\text { Kran }\end{array}$ & $\begin{array}{l}\text { Kenduri, Tapestry and Qom boarding schools and } \\
\text { intellectualism }\end{array}$ \\
\hline
\end{tabular}

Surabaya is one of the centers for the development and spread of Islam in eastern Java with its main character Sunan Ampel and the Ampel Mosque icon, the old mosque in the Ampel Village of Semampir District in the northern region of Surabaya, where majority of the population is Arab. This mosque is one of the religious sights in the city of Surabaya in addition to the al-Akbar National Mosque for residents outside Surabaya or Surabaya residents themselves. The 120x180 square meter mosque was founded in 1421 by Sunan Ampel (one of the nine guardians who spread Islam in Java) whose tomb located in the Ampel Mosque complex [9].

Quoting Rofhani's statement, there are five things related to the expression and representation of middle-class Muslim women. First, related to the personal expression of religious middleclass Muslim women. These expressions are in the form of religious symbols and personal religious activities to assert themselves and their characteristics as middle-class Muslim women. Second, social-religious expression as a means of social recreation and a public statement that they are middle-class Muslim women. This expression takes the form of their activities in the recitation group and social service. Third, representation of the middleclass economy. The representation process is actualized in shopping patterns that explain the motives of middle-class Muslim women when they choose a place for spending time and body care. Fourth, related to fashion and fashion of hijab / hijab as a form of style and appearance and, at the same time, a form of piety as a Muslim. Fifth, the religious relations of the middleclass Muslims with their concept of faith which in this case will be seen exoterically that religion is manifested in the form of material in the form of religious expressions and representations [9], [11], [12].

Riesebrodt mentions the ritual of social piety carried out by middle-class Muslim women in four forms. 1) how intense the obligatory worship and sunnah is carried out, even though at this stage, the sunnah worship develops into identity. 2) how obedient, they carry out orders based on the Qur'an and Hadith. 3) celebration of religious celebrations, 4) interaction of socio-economic values with the value of religiosity. The four indicators are important to see the material dimension is to form an attitude of being godly to the public in the present situation [6], [13].

\section{Beauty Industry: Halal Cosmetics}

The contemporary beauty industry that we know today only developed since the mid-19th century, the era in which advertising agencies began targeting their campaigns for women. The new cosmetics and beauty industry commercialized into a mass industry and became 
something that was fully known to people, only after the end of World War I around the 1920s and 1930s [2].

The inclusion of a variety of beauty industries has succeeded in defining women's bodies as new economic bases, as Tukiman explained that one of the reasons women beautify their bodies is to provide added value to the body that can enhance the body's selling value. The more ideal and beautiful the shape of the body, the higher the economic exchange rate obtained. Women now add "body care" as one part of their routine. In this modern society, any individual who lives in it will use ideas about lifestyle to describe his own actions and those of others. As Lury explains, beauty clinics can focus on women's fantasies, entertainment venues and escape alternatives from the confines of household femininity [14]-[17].

Consumption appears to be a unit of analysis in providing a framework for seeking identity for Middle-class Muslims. Sharia and halal are important indicators in leading Muslim middleclass preferences towards goods products. The boom in the emergence of sharia products is part of the counter hegemony towards the rise of products of East Asian and Western pop culture. The positive implications of increasingly culturing worship become a lifestyle for middle-class Muslims impacting on social piety. The negative implication is that with more casual worship being a lifestyle, then what needs to be considered later is the prestige pursuit that you want to achieve in order to be seen and seen by others. The strengthened consumption of the sharia is confirmed that the teaching of Islam is still in the scriptural level. Sharia is only an icon to invite people to consume these items immediately to become Muslims, but this is not necessarily true and comprehensively adheres to Islamic principles comprehensively [10], [18]-[20].

The production and reproduction cycle of the meaning of beauty is industrial manipulation to legitimize its position as a "beauty supplier". The initial motivation of women in disciplining the body may be to give themselves bargaining power and gain a superior place in various forms of social relations, as a form of resistance to the subordination of women who have been legitimized by the strong influence of capitalism. However, what happened was the absorption of women back into the subordination structure of capitalism through the process of "reaffirming" the old portrait of women as sex objects. As happens in the "ideal" image of women in advertisements [3], [7], [14], [21], [22].

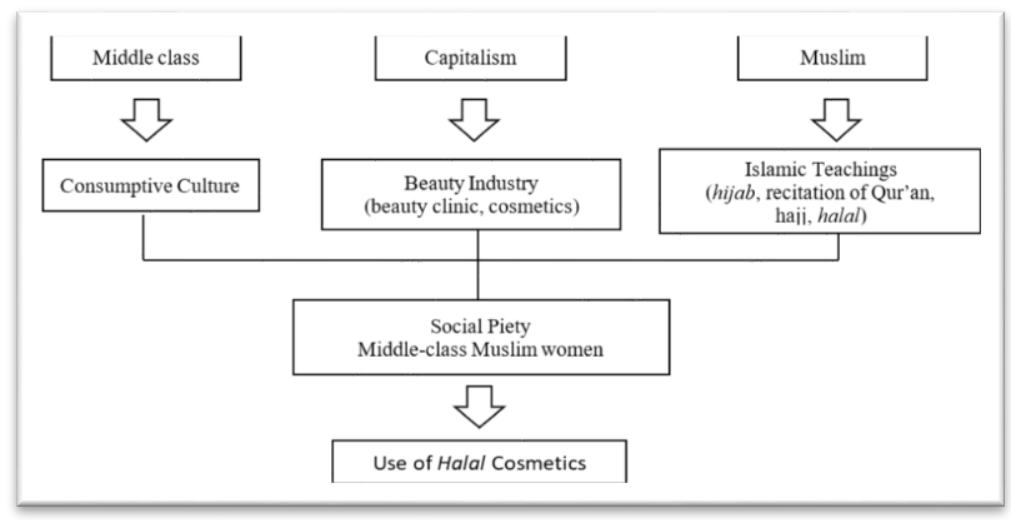

Fig. 1. The use of halal cosmetics as a form of social piety middle class Muslim women 
The meaning of identity of social piety is understood as a form of "materializing spiritual things" and spiritualizing material things ". The practice of social piety for the contemporary Indonesian middle class is seen from how intense the money used to carry out worship and how religious products are to show that it is an Islamic entity. Materialization of worship is then realized in the form of religious symbols in this case in the form of the use of halal cosmetics.[7], [13], [23]

\section{Conclusion}

Two forms of ritual needs for middle-class Muslim women's piety, namely the need for spirituality also the need for existential. First, the spiritual need is seen from how many people carry out social worship in the mosque, how intense it is to run the Hajj and Umrah services, and so on. Spiritual needs themselves are formed because of self-awareness, and needs will be recognized by others. Second, the need for existential is realized by the consumption of commodities that are considered religious and are considered to represent Islam. The imposition of robes, headscarves, and the use of halal cosmetics is an effort to show the existence of oneself that he is a Muslim and obedient people worship with all these things.

The essence of social piety is to increase the level of personal and collective spirituality. The proliferation of various rituals of social piety embodied in mosque-based and non-mosque activities shows that spirituality is an important commodity in shaping social piety. The construction of popular culture has succeeded in suggesting public opinion that by consuming halal products (according to Islamic teachings) in this case the use of halal cosmetics, it will be completely pious. This view then became a common value for the present Muslim middle class.

Acknowledgments. We thank our colleagues from Departments of Social Science and Political Science who provided insight and expertise that greatly assisted the research so that it makes it easier for the authors to participate in the ICEMSS conference program and can develop the knowledge that I concentrate, although they may not agree with all the interpretations/conclusions of this paper.

\section{Reference}

[1] M. H. Kolar, S. Urbančič, and D. Dimitrijević, "Chapter 21 - Nature Knows Best: Where Nature and Beauty Meet," in Nutritional Cosmetics, 2009, pp. 399-419.

[2] D. Paramita, "Kompleks Industri Kecantikan (Sebuah Kritik Sosio Filosofis)," 2007.

[3] A. Safira, "Perceptions of Islamic Advertising Held by Indonesian Muslims," Victoria University of Wellington, 2017.

[4] S. R. Soekarba and N. K. Melati, "Muslim Women in Middle Class Indonesia: Postfeminist Analisis of Women Wearing Veil in Depok (2010-2016)," Int. Rev. Humanit. Stud., vol. 2, no. 1, pp. 75-91, 2017.

[5] A. R. Beta, "Hijabers: How young urban muslim women redefine themselves in Indonesia," Int. Commun. Gaz., vol. 76, no. 4-5, pp. 377-389, 2014.

[6] L. Wong, "Market Cultures, the Middle Classes and Islam: Consuming the Market?," Consum. Mark. Cult., vol. 10, no. 4, pp. 451-480, 2007. 
[7] S. Ali, F. Halim, and N. B. Ahmad, "Beauty Premium and Halal Cosmetics Industry," J. Mark. Manag. Consum. Behav., vol. 1, no. 4, pp. 52-63, 2016.

[8] H. Garfinkel, Studies in Ethnomethodology. NJ: Prentice-Hall, 1967.

[9] Rofhani, "Ekspresi dan Representasi Budaya Perempuan Muslim Kelas Menengah di Surabaya," Islam. J. Stud. Keislaman. Vol. 11, Nomor 2, Maret 2017., pp. 277-310, 2017.

[10] W. Raharjo Jati, "Islam Populer sebagai Pencarian Identitas Muslim Kelas Menengah Indonesia," Teosof. J. Tasawuf dan Pemikir. Islam, vol. 5, no. 1, pp. 139-163, 2015.

[11] A.-M. Almila and D. Inglis, The Routledge international handbook to veils and veiling practices. 2018.

[12] E. Tarlo, "Hijab in London: Metamorphosis, resonance and effects," J. Mater. Cult., vol. 12, no. 2, pp. 131-156, 2007.

[13] W. R. Jati, “Kesalehan Sosial Sebagai Ritual Kelas menengah Muslim,” Ibda' J. Kebud. Islam, vol. 13, no. 2, pp. 336-349, 2015.

[14] A. Simanjuntak, "Industrialisasi Kecantikan: Histeria Kegelisahan \& Pendisiplinan Tubuh Perempuan.” pp. 1-12.

[15] S. Murlianti, "Cycles of Beauty Culture : Ethnography of Beauty Clinics Commodification," J. Komunitas, vol. 6, no. 2, pp. 189-196, 2014.

[16] W. Luo, "Aching for the altered body: Beauty economy and Chinese women's consumption of cosmetic surgery," Womens. Stud. Int. Forum, vol. 38, pp. 1-10, 2013.

[17] K. T. Frith, "Globalizing Beauty: A Cultural History of the Global Beauty Industry TITLE : Globalizing Beauty: A Cultural History of the Global Beauty Industry," no. May, pp. 1-33, 2014.

[18] W. S. Utama, "Incorporating Spirituality and Market : Islamic Sharia Business and Religious Life in Post-New Order Indonesia," Masy. J. Sosiol., vol. 20, no. 80, pp. 113-137, 2016.

[19] S. H. Hassan and H. Harun, "Factors influencing fashion consciousness in hijab fashion consumption among hijabistas," J. Islam. Mark., 2016.

[20] J. Fischer, The Halal Frontier: Muslim Consumers in a Globalized Market, 1st ed., vol. 53, no. 9. New York: Palgrave Macmillan, 2011.

[21] K. Kaur, N. Arumugam, and N. M. Yunus, "Beauty product advertisements: A critical discourse analysis," Asian Soc. Sci., vol. 9, no. 3, 2013.

[22] R. Hussin, S. H. Yusoff, and S. N. M. Yusof, "Islamic Representation in Television Advertising and its Impact on Modern Malay Muslim Women," Procedia - Soc. Behav. Sci., vol. 211, pp. 890-895, Nov. 2015.

[23] B. L. Yeo and R. H. N. Mohamed, "A Study of Malaysian Customers Purchase Motivation of Halal Cosmetics Retail Products: Examining Theory of Consumption Value and Customer Satisfaction," Procedia Econ. Financ., vol. 37, pp. 176-182, Jan. 2016.

[24] P. Febriana and R. Y. Sari, "Islam Commodification Through Halal Cosmetics in Indonesia."

[25] A. Abd Rahman, E. Asrarhaghighi, and S. Ab Rahman, "Consumers and halal cosmetic products: Knowledge, religiosity, attitude and intention," J. Islam. Mark., vol. 6, no. 1, pp. 148-163, 2015.

[26] N. M. Daud, H. A. Aziz, N. H. Baharudin, and S. F. Shamsudin, "Identifying the Determinant Attributes of Halal Cosmetics Product That Influence Its Positioning Strategy in Malaysian Market," J. Appl. Sci. Res., vol. 8, no. 1, pp. 301-313, 2012. 
[27] A. J. bt C. M. Hashim and R. Musa, "Factors Influencing Attitude towards Halal Cosmetic among Young Adult Urban Muslim Women: A Focus Group Analysis," Procedia - Soc. Behav. Sci., vol. 130, pp. 129-134, May 2014.

[28] F. Mohammadian, B. Hajipour, and S. Beheshti, "Halal Cosmetics Supply Chain - A Conceptual Model," Int. J. supply Chain, vol. 5, no. 1, pp. 33-43, 2015.

[29] I. A. L. Tournois, I. Aoun, and L. Tournois, "Building holistic brands: an exploratory study of Halal cosmetics,” J. Islam. Mark., vol. 6, no. 1, 2015. 